\title{
THE STRUCTURE AND GENESIS OF ONE TYPE OF MAGIC SPELL AGAINST CHILDREN'S INSOMNIA AMONG SLAVIC PEOPLES
}

\author{
Tatiana Agapkina \\ Leading Research Fellow, Sc.D. \\ Institute for Slavic Studies \\ Russian Academy of Sciences, Russia \\ agapi-t@yandex.ru
}

\author{
Andrei Toporkov \\ Leading Research Fellow, Sc.D. \\ Corresponding Member of the Russian Academy of Sciences \\ Gorky Institute of World Literature, Russia \\ atoporkov@mail.ru
}

\begin{abstract}
Among Slavic charms for children who suffer from insomnia, there are texts depicting mothers going out of their houses, carrying their babies while looking at the forest or a single tree and reciting a magic spell addressed to a mythological character, asking for the creature's help in taking away the baby's cries and restoring the baby's sleep. One variation of such texts originates from a manuscript called Summa de confessionis discretione. This text was compiled in Latin by a monk named Rudolf, evidently in the middle of the thirteenth or the beginning of the fourteenth century. The fact that the magic spells for insomnia in children seem to have existed already in the thirteenth or fourteenth century, and that in the nineteenth and twentieth centuries they were widely spread on the broad territory where Eastern, Southern, and Western Slavs lived, testifies to the ancient origins of this type of magic spell.
\end{abstract}

Keywords: Forest Mother, insomnia, monk Rudolf, Slavic charms, Summa de confessionis discretione, Upper Silesia

\section{INTRODUCTION}

Magical charms for children who suffer from insomnia and night crying are widely known among various Slavic peoples. Of special interest are texts where a mother of a child suffering from insomnia goes out of the house carrying the baby, looks at the forest or a single tree and recites a magic spell addressed 
to a mythological character (for example, the forest woman - lesnaya baba) or a natural object (such as a forest, an oak), asking for the creature's help in taking away the baby's cries and restoring the baby's sleep (Budziszewska 1982; Vinogradova 1988; 2016: 269-278; Agapkina \& Toporkov 1990; Agapkina 2010: 264-269; 2019).

Similar texts were recorded numerous times in the nineteenth-twentieth centuries among Eastern Slavs (mostly among Ukrainians and Belarusians) as well as among Southern Slavs (Serbs and Bulgarians); among Western Slavs (Poles and Czechs) only single instances are known. Outside the Slavic world, these texts were also recorded among Romanians. The quantitative ratio between discovered texts is as follows: Ukrainian texts - 49, Belorussian - 45, Russian - 6, Serbian - 5, Bulgarian - 5, Czech - 1, Polish - 1, Romanian - 2.

\section{THE STRUCTURE OF MAGIC SPELLS FOR INSOMNIA IN CHILDREN}

For this type of magic spell, the following structural elements are common:

1. As a rule, these magic spells are addressed to mythological creatures (the forest woman - lesnaya baba, the old forest couple - lesnye baba $i$ ded) or to natural objects such as the forest itself, an oak, etc. The forest and the trees themselves (oaks and birches) are personified and often perceived as mythological creatures. These magic spells can be addressed to a sunset or to specific heavenly bodies.

2 . The spell's characters include a mother and her child and a female mythological creature and her child. In this case, the human mother and her child are taken as real, while the mythological creature and her child belong to an imaginary world. Many texts specifically mention that the human baby and the baby of the mythological creature are of opposite genders. Thus, if the human woman has a boy, then the mythological creature's child is a girl and vice versa. Some magic spells express a wish that these children marry, or that one child misses the other.

A number of publications contain two variations of the same text which vary in structure depending on the gender of the suffering child. Below we demonstrate an appeal to the trees from a Ukrainian magic spell:

(Коли хлопеиь): Дубе, дубе зеленьй! Маєшь дочки, березки. ... (Коли девчина): Березе, березе зеленая! Маєшь дубки, сынки... (Balagur 1847: 267-268). 
(If it is a boy) Oak, green oak! Your daughters are birch-trees. ... (If it is a girl): Birch-tree, green birch-tree! Your sons are oaks...

3. If we consider the dynamics of a magic spell, we should denote two situations - its beginning and its end, and we can identify the exchange of human and mythological babies' states, crying for silence. At the beginning of a magic spell, a woman's child is crying while the child of a mythological creature is sleeping quietly. After this, a wish is stated that the woman's child would, in turn, sleep quietly, while the child of the mythological creature would cry.

4. The desired situation should be the result of concrete actions taken by the subject performing a magic spell. On the one hand, a woman offers to form friendly relationships and even kinship between herself and the mythological creature. On the other hand, she asks the mythological creature to take away her baby's night crying and return it to sleep and peace. In Ukrainian and Belorussian magic spells, the offers to establish kinship are often expressed by the words 'posvataiemsya, pobrataiemsya', which may be translated as 'let's become relatives by marrying our children', and 'we will be sisters- and brothers-in-law'.

Thus, the process of healing a baby's insomnia is described in magic spells as a specific exchange of crying and sleep - crying for sleep and sleep for crying. Both are presented as material objects. In so doing, the idea of exchange and the idea of establishing kinship are reconciled with each other, because in folk culture recognition of symbolical kinship or fraternizing, as a rule, are accompanied by bodily contact (handshakes, kisses) and the exchange of personal items. We propose that in this case sleep and night crying serve as symbolical values, exchanges of which result in the formation of an artificial kinship between a human and a mythological creature.

5. In various Slavic traditions, the desires expressed by a subject of a magic spell are slightly different, but they can generally be summed up to three basic variants:

5.1. A woman informs a female mythological creature that she has a son, and the creature has a daughter (or vice versa), and offers to take away night crying of her baby. Here is an example from the Ukrainian magic spell:

Lis-lisowyna, pobratajemosia, poswatajemosia, u tebe doczka, a u mene syn; woźmy sobi s mojoho syna $i$ uroki-uroczyszcza... (Talko-Hryncewicz 1893: 214-215, № 24)

Forest, forest, let's be sworn brothers, let's be match-makers, you have a daughter, and I have a son; take bad luck from my son... 
5.2. A woman informs a mythological creature that she has a son, and a creature has a daughter (or vice versa), and offers to marry them. Here is an example from the Belorussian magic spell:

Zara-zaryca, Bożaja pamacznica, jość u Ciabie synok Wasilok (księżyc), a u mianie daczuszka (Hanulka), budziem ich żanić umieście! Jość u (Hanulki) babka-Bożaja matka, waźmi Ty jaje krywatù, tamatù i kryksy i płaksy rannyja i poznyja, paudnyja i dziannyja i daj jej son! (Wereńko 1896: 207, № 16)

Dawn-dawn, God's helper, you have a son, Vasilyok (the moon), and I have a daughter (Ganul'ka), we will marry them! (Ganul'ka) has a granny who is God's mother, take her crookedness, throbbing and crying early in the morning and late in the evening, during afternoon and during the day, and give her sleep!

5.3. A woman informs a mythological creature that up until then her baby has been crying about the baby of a mythological creature, and says that in the future the baby of the mythological creature will be crying about her baby. Consider a Serbian magic spell:

О, шумина мати, до сад плака моје дете за твојил дететол, а од сад нека плаче твоје дете из-за мојил! (Grbich 1909: 124)

Oh, forest mother, until now my baby has been crying about your baby, and from now on let your baby cry about my baby!

\section{MAGICAL TEXT FROM SUMMA DE CONFESSIONIS DISCRETIONE}

This group of magic spells has attracted special attention because one of the variants of these texts occurs in a manuscript called Summa de confessionis discretione, compiled in Latin by a monk called Rudolf, evidently in the middle of the thirteenth or the beginning of the fourteenth century. The handbook was stored in the Cistercian monastery of Rudy in Upper Silesia (near the modern Polish city of Katowice), and was later given to the university library in Wroclaw, where it is preserved now.

Included in the manuscript is an array of guides for confessors in their confessional practice - and it is known in academic literature as The Catalog of Magic by the Cistercian monk Rudolf. Three chapters of these penitentials (chapters VIII, IX, and X) are devoted to the rites and beliefs of local people. The manuscript describes, in detail, magic actions performed on behalf of children 
(chapter VIII), magic actions carried out by virgins and married women (chapter IX), and magic actions aiming to achieve happiness (chapter X). The materials in each section are presented systematically, accompanied by detailed descriptions of ritual actions and separate magic formulas. All of these observations suggest that the compiler had witnessed at least some of the described ethnographical facts.

For the first time, The Catalog of Magic was published by Joseph Klapper in 1915, parallel with a German translation (Klapper 1915). In 1955 Edward Karwot published The Catalog of Magic in Polish along with extensive research (Karwot 1955). Karwot calculated that the manuscript was compiled in Upper Silesia between 1235 and 1250, while not denying the possibility that Rudolf had collected some of the materials earlier in Małopolska, since the Rudy Cistercian monastery had been founded around 1255 by Prince Vladislav I of Opole, who relocated monks from Jędrzejów monastery in Małopolska.

Later on investigation of The Catalog of Magic developed along two basic directions of analysis. On the one hand, scholars analyzed the manuscript itself, which included Summa de confessionis discretione, the place of the manuscript in the Rudy Cistercian library, and the place of The Catalog of Magic in the religious and cultural context of the thirteenth-fourteenth centuries. On the other hand, scholars investigated folklore beliefs and magical practices, which were described by Rudolf, comparing them to similar beliefs and practices among Poles, Germans, and other Slavic and Germanic peoples (Barnat 2000; Bracha 2000; Smoczyńska-Reiner 2007).

While researching The Catalog of Magic, scholars have made many valuable observations, but there is no general agreement on the ethnicity of people practicing the rites described in the manuscript. If Karwot believed that Rudolf documented the customs of Slavic peoples from Upper Silesia or Małopolska, then Klapper and a group of researchers from the end of the twentieth century until the beginning of the twenty-first century thought that Rudolf described German beliefs. There remains an array of questions as to when and where Summa de confessionis discretione was compiled as well as what Brother Rudolf's ethnicity might have been.

We do not propose to settle the question of the origins of The Catalog of Magic but present a more modest project. The subject of our attention is a section in The Catalog of Magic devoted to the magic practice of calming babies who did not sleep at night and whose crying bothered those around them:

Retro ostium stantes vespere puerum in sinu gestantes vocant mulierem silvestrem, quod faunam dicimus ut puer fauni ploret, suus taceat (Karwot 1955: 23). 
In the evening, carrying a baby, someone goes out of doors and calls a forest woman, who we call Fauna, to make Fauna's baby cry, and their baby silent.

As far as we know, similar German magic spells have never been recorded, yet at the same time there are more than 100 similar texts documented among Slavic peoples, collected from the spread territory where Eastern, Southern, and Western Slavs lived.

The fact that the text was written down in Latin makes studying it more complicated, especially when there is no certainty about the original language (Slavic or German) in which it was recited. What is important is that Slavic tradition includes texts which provide parallels to the text from The Catalog of Magic not only in terms of separate words and phrases but also in terms of rites and related pagan beliefs. The parameters for comparison include the pragmatics of the ritual and its location, the mythological 'forest woman' and, finally, the tactics of human behavior towards otherworldly spirits.

\section{THE CHARM AGAINST CHILDREN'S INSOMNIA IN SLAVIC TRADITION}

Despite the fact that the text in Latin is concise, it does make it possible to judge which magical practices were used by Rudolf's informants to return a disturbed child to healthy sleep, and which magical formulas were recited during the ritual.

1. Although Rudolf's record does not say who performed this ritual, it is fairly obvious that it was a mother of a child or a female healer. We can say with a great deal of confidence that the ritual was performed by a woman and not by a man, because among Slavic and Germanic people the whole sphere of magic healing related to small children was controlled exclusively by women.

2. It is obvious that the ritual was performed over a baby because, according to Rudolf's description, the baby was held in somebody's hands. The woman was supposed to leave the house to perform this ritual. However, Rudolf did not say how far the woman went away from the house; by analogy with Slavic rituals recorded in the nineteenth-twentieth centuries we may guess that she performed a magic spell standing near the door of her house while looking at the forest or at a single tree somewhere nearby. Here is an example of a parallel description of a similar ritual recorded in Podol'ye (Ukraine) in 1867: 
For insomnia: in the morning before dawn stand at the place where trash from the house is thrown, look at the forest, first say the Lord's prayer, and then say the following:

"Добри вічір тобі ліси недобори; посватайлося и побратайлося, ти маешь сына, а я маю дочку ... на тобі плаксавицю, дай міні соновищю, нихай ні спит, ні дрілае, нихай по лісі гуляе, алоя хрещена порожена нихай спит як день, так нічь."

Good evening to you, forest, let's do match-making and be in-laws; you have a son, and I have a daughter ... take the crier, give me a sleeper, let [your baby] not sleep, not nap, let [your baby] walk in the forest, and my baptized [daughter], born by me, let her sleep day and night.

... You should certainly look at the forest; otherwise, according to the healer's words, you will take away sleep from the one whose house you are looking at. (M.B. 1867: 694)

Thus, the special structure of this ritual described in the nineteenth-twentieth centuries implies a relationship of two locations - a human habitation and forest, establishing contact between them via a human glance. Since Rudolf's record is rather brief, we cannot be certain about the place of the ceremony he described, but it is likely that the ritual referred to in the manuscript was not much different from the ones we found in the nineteenth- and twentiethcentury materials.

3. According to Brother Rudolf, the magic spell was addressed to 'the forest woman who we call Fauna'. Obviously, the bearers of tradition called this character the forest woman, and the expression 'which we call Fauna' is Rudolf's glossary. The fragment focusing on a 'forest woman who we call Fauna' is somewhere in between the ritual description (which is at the beginning of the record) and magic formula 'to make Fauna's baby cry, and their baby would become silent,' which completes the record.

In the similar Slavic and Romanian magic spells, recorded in the nineteenth and twentieth centuries, there are also words addressed to the forest woman or the forest mother, for example: Belorussian баба барава, лесавая баба, лисавая баба Марына, лесовые дзедь и бабы; Bulgarian баба Гора, горска майка; Serbian горска мајка, горска вештица, шулина мати; Romanian muma pădurii [mother of the forest]. In The Catalog of Magic and in the magic spells recorded in the nineteenth and twentieth centuries the forest woman is somehow connected with children's insomnia, because people addressed their words especially to her to help a child stop crying during the night. 
4. According to Rudolf's text, the forest woman also had her own child. The system of characters is based on the symmetry between a mythological forest world and the real human world, and includes at least four characters: the forest woman, the child of the forest woman, the human woman, and the child of the human woman. The ritual has a form of a dialogue between the woman and the mythological creature, the first using a magic formula; in response she expects help in healing her baby. It is interesting that she expects the forest creature to help solve her family problems; i.e., the forest world has a quite positive value. It may also be noted that Brother Rudolf does not blame the ritual performer worshiping evil spirits and does not condemn her; he documents the ritual in a neutral and objective way, the same way as a modern ethnographer would document this fact.

5. The text completes with the words 'let Fauna's baby cry, and my baby be silent', which define the purpose of the ritual. It seems that Rudolf's record rather closely conveys the magic formula which was part of the ritual. Obviously, in the original text the forest woman was mentioned and not Fauna, as she was called by Rudolf. Hypothetically, this formula could sound the following way: 'Let your child (or the child of 'the forest woman') cry, and my child be silent'.

There is little or no doubt that the magic spell laconically retold by Brother Rudolf had a longer original form. This produces some reservations about the text under consideration. In particular, it is unclear why the forest woman should accept such an unprofitable offer.

To resolve this question, it is helpful to review the records made in the nineteenth and twentieth centuries, which are significantly more comprehensive than Rudolf's. We have already outlined three basic variations of this type of the spell for children's insomnia. In the most widespread variants of this plot the woman offers the mythological being to exchange the cry of her baby for the sleep of the forest woman's child. That is, the situation is described as an exchange between a representative of the human world and a mythological forest character.

The pragmatic purpose of the magic spell is described in a way as to hide the real aim of the woman and to encourage the forest woman to accept an unprofitable deal. Using the tactic of deception, the performer of the magic spell offers the forest woman a mutually beneficial exchange, which seems to establish a kinship relationship between the human mother and the forest woman. Actually, the aim is to free her own child from crying and to transfer the crying to the child of the forest woman. 
In the texts of the second type, the woman proposes to a mythological being that their children marry, and in the texts of the third group it is suggested that the children have some feelings for each other. In both cases the pragmatic purpose of the magic spell is being concealed. It seems that the tactic of lying was quite acceptable for people who used magic for resolving their own problems and communicated with mythological creatures.

\section{CONCLUSION}

Thus, with the help of magic spells recorded in the nineteenth-twentieth centuries, it is possible to reconstruct hypothetically the inner logic and missing links of the medieval magical text, which Brother Rudolf recorded in an abbreviated form. Keeping in mind that the record not only has separate parallels in Slavic ethnographic materials of the nineteenth and twentieth centuries, but is also an organic part of the Slavic tradition, we could naturally assume that in this case Brother Rudolf received information from the Slavic bearers of tradition, who most likely told him this spell in Polish.

We do not attempt to extrapolate our conclusions about the Slavic origin of just one of Rudolf's records to the entire volume of The Catalog of Magic, but we also believe that it would be incorrect to totally ignore this observation.

The fact that the magic spells for children's insomnia which we analyzed seem to have existed already in the thirteenth or fourteenth century, and that in the nineteenth and twentieth centuries they were widely spread on the broad territory where Eastern, Southern, and Western Slavs lived, testifies to the ancient origins of this type of magic spells and their centuries-old migration on the territory of Eastern, Southeastern, and Central Europe.

\section{Translated by Yelena Minyonok}

\section{ACKNOWLEDGEMENTS}

This work was supported by the Russian Foundation for Basic Research (grant number 20-012-00117, "Russian magic folklore from unpublished sources from the 17th to the start of the 20th century; archival searches, preparation of scientific publication, research, and commentary"). 


\section{REFERENCES}

Agapkina, Tatiana 2010. Vostochnoslavianskie lechebnye zagovory v sravnitel'nom osveshchenii: Siuzhetika i obraz mira. [Eastern-Slavic Magical Healing Spells in Comparative Studies: Plots and the Image of the World.] Moscow: Indrik. Available at https://inslav.ru/images/stories/pdf/2010_Agapkina_Zagovory.pdf, last accessed on 10 September 2020.

Agapkina, Tatiana 2019. Paralleli v oblasti verbal'noi magii u vostochnykh i iuzhnykh slavian. [Parallels in the Sphere of Verbal Magic among Eastern and Southern Slavs.] In: Svetlana Tolstaia (ed.) Slavianskie arkhaicheskie arealy v prostranstve Evropy. Moscow: Indrik, pp. 10-38. Available at https://inslav.ru/sites/default/files/ editions/2019_slavjanskie_arxaicheskie_arealy.pdf, last accessed on 10 September 2020 .

Agapkina, Tatiana \& Toporkov, Andrei 1990. K rekonstruktsii praslavianskikh zagovorov. [To the Recomposition of Proto-Slavic Magic Spells.] In: Boris Putilov (ed.) Fol'klor i etnografiia: problemy rekonstruktsii faktov traditsionnoi kul'tury. Leningrad: Nauka, pp. 67-75. Available at https://www.academia.edu/5268605/K_ реконструкции_праславянских_заговоров, last accessed on 10 September 2020.

Balagur, Iats'ko 1847. Vorozhenie u rusinov. [Working with Magic among Rusyns.] In: Ivan Golovatskii (comp.) Venok rusinam na obzhinki. Part 2. Vienna: O.O. Mekhitaristov, pp. 262-272. Available at http://history-fiction.ru/books/ all_1/region_110_1/book_4340/, last accessed on 10 September 2020.

Barnat, Roman 2000. Problem wierzeń demonologicznych w Katalogu magii Rudolfa. [Problems of Mythological Beliefs in Rudolf's Catalog of Magic.] In: Antoni Barciak \& Teresa Rduch (eds.) Z dziejów Śląska: Zbiór studiów. Katowice: PAN O/ Katowice, pp. 9-27.

Bracha, Krzysztof 2000. Katalog magii Rudolfa (na marginesie dotychczasowych prac). [Rudolf's Catalog of Magic (on the Margins of the Previous Works).] In: Józef Dobosz \& Andrzej Marek Wyrwa (eds.) Cystersi w społeczeństwie Europy Środkowej: Materiaty z konferencji naukowej odbytej w klasztorze oo. Cystersów w Krakowie Mogile z okazji 900 rocznicy powstania Zakonu Ojców Cystersów, Poznań - Kraków - Mogita, 5-10 października 1998. Poznań: Wydawnictwo Poznańskie, pp. 806-820. Available at https://www.academia.edu/39845013/ Bracha_K._Katalog_magii_Rudolfa, last accessed on 10 September 2020.

Budziszewska, Wanda 1982. Fauna z Katalogu magii brata Rudolfa. [Fauna from Brother Rudolf's Catalog of Magic.] Poradnik językowy, Vol. 6, pp. 411-414. Available at https://poradnik-jezykowy.uw.edu.pl/issue/946, last accessed on 10 September 2020.

Grbich, Savatije 1909. Srpski narodni obichaji iz sreza Bolievachkog. [Serbian Folklore Customs from Bolevachkog County.] Srpski etnografski zbornik, Volume 14. Obichai naroda srpskoga. Book 2. Beograd: Drzhavna shtampariia Kralievine Srbiie, pp. 1-382. Available at https://www.antikvarne-knjige.com/elektronskeknjige/ assets/uploads/obicaji-naroda-srpskog-2.pdf, last accessed on 10 September 2020. 
Karwot, Edward 1955. Katalog magii Rudolfa: Źródto etnograficzne XIII wieku. [The Rudolf' Catalog of Magic: An Ethnographic Source of the 13th Century.] Wroclaw: Zakład im. Ossolińskich.

Klapper, Joseph 1915. Deutscher Volksglaube in Schlesien in ältester Zeit. Mitteilungen der Schlesischen Gesellschaft für Volkskunde, Vol. 17, pp. 19-57. Available at https://sbc.org.pl/Content/304952/ii4045-1915-01-0001.pdf, last accessed on 10 September 2020.

M.B. 1867. Sel'skie chary i zagovory - po Podol'skoi gubernii. [Countryside Magic and Magic Spells - in Podolsk Province.] Podol'skie eparkhial'nye vedomosti. Otdel neofitsial'nyi, No. 20, 15 October, pp. 689-695. Available at https://pravoslavnoeduhovenstvo.ru/media/priestdb/materialattachment/attachment/a5/a5/a5a503817b87-4824-9473-517a02a8fd39.pdf, last accessed on 11 September 2020.

Smoczyńska-Reiner, Daria 2007. Świat pogańskich wierzeń ludowych w dziele "Summa de confessionis discretione" brata Rudolfa. [The World of Pagan Folk Beliefs in "Summa de Confessionis Discretione" by Monk Rudolph.] Slavia Antiqua: rocznik poświęcony starożytnościom stowiańskim, Vol. 48, pp. 189-248. Available at http://cejsh.icm.edu.pl/cejsh/element/bwmeta1.element.38f4aa23-d63d3567-aa5d-2e1807dfde0f, last accessed on 11 September 2020.

Talko-Hryncewicz, Julian 1893. Zarysy lecznictwa ludowego na Rusi potudniowej. [Essays on Traditional Medicine in Southern Russia.] Kraków: Nakł. Akademii Umiejętności: Skł.gł. w Księgarni Spółki Wydawniczej Polskiej. Available at https://books.google.ru/books?id=xWvESIvADJ8C\&printsec=frontcover\&hl=ru \#v=onepage\&q\&f=false, last accessed on 11 September 2020.

Vinogradova, Liudmila 1988. Slavianskie zagovornye formuly ot detskoi bessonnitsy. [Slavic Magic Formulas for Insomnia in Children.] Etnolingvistika teksta: Semiotika malykh form fol'klora. Tezisy i predvaritel'nye materialy $k$ simpoziumu. Vol. 1. Moscow: Institut slavianovedeniia i balkanistiki AN SSSR, pp. 82-85. Available at https://inslav.ru/images/stories/pdf/1988_Etnolingvistika_ teksta_\%28Semiotika_malyx_form_folklora\%29_Tezisy.pdf, last accessed on 11 September 2020.

Vinogradova, Liudmila 2016. Mifologicheskii aspekt slavianskoi fol'klornoi traditsii. [Mythological Aspect of Slavic Folklore Tradition.] Moscow: Indrik.

Wereńko, F. 1896. Przyczynek do lecznictwa ludowego. [Contribution to Traditional Medicine.] In: Materiaty antropologiczno-archeologiczne i etnograficzne. T. 1, Dz. 2. Kraków: Nakł. Akademii Umiejętności, pp. 99-228. Available at https://rcin. org.pl/dlibra/show-content/publication/edition/1496?id=1496, last accessed on 11 September 2020.

Tatiana Agapkina is Leading Research Fellow (Sc.D.) at the Institute for Slavic Studies, Russian Academy of Sciences, Moscow, Russia. Her main research areas are calendar rites, ethnobotany, and verbal magic.

agapi-t@yandex.ru 
Andrei Toporkov is correspondent member of the Russian Academy of Sciences, Leading Research Fellow (Sc.D.) at the Gorky Institute of World Literature, Russian Academy of Sciences, Moscow, Russia. His main research areas include Russian and Slavic folklore and history of Russian literature.

atoporkov@mail.ru 